Eliza Nel Jurkianiec ${ }^{*}$

\title{
DECENTRALIZACJA W POLSKIM SYSTEMIE OCHRONY ŚRODOWISKA
}

\section{Pojęcie decentralizacji}

Pojęcie decentralizacji może mieć wielorakie znaczenie, w zależności od tego, na gruncie jakiej nauki jest rozpatrywane. W obszarze nauk prawnych należy pamiętać, że zasada decentralizacji została wyrażona w art. 15 ust. 1 Konstytucji RP, zgodnie z którym: „Ustrój terytorialny Rzeczypospolitej Polskiej zapewnia decentralizację władzy publicznej”. Oznacza ona taki sposób organizacji aparatu administracyjnego, w którym brak jest hierarchicznego podporządkowania organów niższego stopnia organom wyższego stopnia, ingerencja w zakres ich działania może odbywać się tylko na podstawie ustawy i w formach przewidzianych przez prawo, a poszczególne ogniwa tego aparatu mają samodzielność w realizacji zadań nań nałożonych ${ }^{1}$. Odnosząc się do samodzielności, należy mieć na uwadze samodzielność finansową. Ważne jest, by zdecentralizowany organ został wyposażony we własne źródła dochodu oraz by mógł samodzielnie decydować o sposobie wydatkowania środków finansowych, innymi słowy - by posiadał samodzielność finansową ${ }^{2}$.

Eliza Nel Jurkianiec - Instytut Nauk Prawnych PAN.

${ }^{1}$ Szerzej A. Skoczylas, W. Piątek, Uwagi do art. 15 [w:] Konstytucja RP. Komentarz, red. M. Safjan L. Bosek, Warszawa 2016, s. 403-405.

2 Zob. E. Zieliński, Administracja rządowa i samorzq̨dowa $w$ Polsce, Warszawa 2013, s. 68 . 
„Podstawowymi podmiotami zdecentralizowanymi w obrębie aparatu państwowego są jednostki samorządu terytorialnego szczebla gminnego, powiatowego i wojewódzkiego"3. Zasada decentralizacji władzy publicznej wyrażona w Konstytucji RP jest realizowana poprzez ustawy ustrojowe o samorządzie terytorialnym: u.s.g., u.s.p. i u.s.w.

\section{System ochrony środowiska}

Prawo środowiska uznawane jest za jeden z najmłodszych kierunków regulacji prawnej, gdyż jego początek datuje się w Polsce na koniec lat 60. i początek lat 70. XX w. Podstawowym aktem prawnym w systemie polskiego prawa ochrony środowiska jest ustawa z 27.04.2001 r. Prawo ochrony środowiska ${ }^{4}$, która zastąpiła od 1.10.2001 r. ustawę z 31.01.1980 r. o ochronie i kształtowaniu środowiska ${ }^{5}$. Ustawa podzielona jest na tytuły: „Przepisy ogólne”, „Ochrona zasobów środowiska”, „Przeciwdziałanie zanieczyszczeniom”, „Poważne awarie”, „Środki finansowo-prawne”, „Odpowiedzialność w ochronie środowiska”, „Organy administracji oraz instytucje ochrony środowiska”. Ustawa „zawiera regulacje o charakterze ogólnym, dotyczące środowiska jak o całości i jego poszczególnych elementów, pozostawiając jednocześnie odrębnym regulacjom szczegółowe przepisy odnoszące się do poszczególnych elementów bądź czynników wpływających na jego zanieczyszczenie lub ochronę"6. Dotyczą one:

1) ochrony przyrody;

2) substancji chemicznych;

3) substancji zubożających warstwę ozonową;

4) rolnictwa ekologicznego;

5) odpadów i odpadów komunalnych;

6) prawa wodnego;

7) ochrony gruntów rolnych i leśnych;

${ }^{3}$ E. Zieliński, Administracja..., s. 68.

${ }^{4}$ Dz.U. z 2018 r. poz. 799 ze zm. - dalej jako: p.o.ś.

5 Dz.U. z 1994 r. Nr 49, poz. 196 ze zm.

6 Zob. J. Ciechanowicz-McLean, Prawo ochrony i zarządzania środowiskiem, Warszawa 2015, s. 39. 
8) lasów;

9) narodowego charakteru strategicznych zasobów naturalnych kraju;

10) udziału społeczeństwa w ochronie środowiska;

11) ocen oddziaływania na środowisko i jeszcze kilku innych? ${ }^{7}$.

Jak stwierdza J. Ciechanowicz-McLean: „pomimo formalnej równości wymienionych wyżej aktów prawnych rangi ustawowej ustawa - Prawo ochrony środowiska jest wiodącym aktem prawnym i porządkującym ten system. Celem ustawy jest stworzenie podstawy ochrony wszystkich elementów środowiska oraz środowiska jako całości, także w miarę możliwości ujednolicenie wymagań i procedur w tej dziedzinie"8.

Znamienną cechą prawa ochrony środowiska jako systemu prawnego jest to, że jest ono systemem otwartym, co wynika przede wszystkim z istoty samej problematyki ochronnej. Nowe rozwiązania technologiczne czy konstrukcyjne powodują narastanie coraz to nowych zagrożeń, wymagających interwencji prawodawczej ${ }^{9}$.

\section{Model administrowania sprawami ochrony środowiska w Polsce}

Jednym z głównych zadań samorządu terytorialnego jest ochrona środowiska. Reformy administracji przeprowadzone w Polsce w 1990 r., a następnie w 1998 r., dały podwaliny decentralizacji administracji państwowej. Stworzone zostały warunki, by na poziomie centralnym realizowane były zadania o charakterze ogólnokrajowym, natomiast na odpowiednich stopniach samorządu terytorialnego by mogły być realizowane sprawy o treści lokalnej i regionalnej. Nastąpiło przekazanie wspólnotom samorządowym kompetencji administracji

7 Zob. J. Ciechanowicz-McLean, Prawo..., s. 39.

8 Zob. J. Ciechanowicz-McLean, Ochrona środowiska $w$ działalności gospodarczej, Warszawa 2003, s. 19-21.

9 Zob. R. Paczuski, Ochrona środowiska. Zarys wykładu, Bydgoszcz 2008, s. 111. 
państwowej oraz związanych z nimi środków finansowych, a także sformułowane zostały podstawy prawne zapewniające samodzielne wykonanie przekazanych zadań. Głównym założeniem zmian było, aby prawo realizowano w sposób najbardziej bezpośredni. Na skutek decentralizacji sprawy o charakterze lokalnym podejmowane są przez gminę i powiat, natomiast samorządowe województwo realizuje zadania o znaczeniu regionalnym ${ }^{10}$.

Reformy ustrojowe państwa z 1990 r. i 1998 r. oraz Prawo ochrony środowiska spowodowały, że zmianie uległa dotychczasowa struktura organów ochrony środowiska. Zasadniczym elementem dokonanych przekształceń była dalsza decentralizacja zadań środowiskowych na rzecz samorządu terytorialnego. Udział jednostek samorządu terytorialnego w procesie zarządzania środowiskiem miał zapewnić poprawę jakości życia lokalnych społeczności i przede wszystkim realizację zasady zrównoważonego rozwoju ${ }^{11}$.

Zgodnie z art. 5 Konstytucji RP Rzeczpospolita Polska „zapewnia ochronę środowiska, kierując się zasadą zrównoważonego rozwoju”. Zatem ochrona środowiska jest obowiązkiem władzy publicznej. Przepis ten wskazuje podstawowe cele i zarazem zadania państwa. Realizacja wymienionych w tym przepisie zadań należy jednak do wszystkich władz publicznych Rzeczypospolitej - zarówno władzy ustawodawczej, jak i wykonawczej, a także do organów sądowniczych i organów samorządu terytorialnego ${ }^{12}$. Dodatkowo mocą art. 86 Konstytucji RP ustanowiony został powszechny obowiązek dbałości o stan środowiska. „Zapewnienie ochrony środowiska”, o którym mowa w art. 5 Konstytucji RP, oznacza „nie tylko zapewnienie mieszkańcom nieskażonego powietrza, zdrowej wody pitnej czy terenów

${ }^{10}$ Zob. A. Barczak, E. Kowalewska, Zadania samorządu terytorialnego w zakresie ochrony środowiska. Aspekty materialne i finansowe, Warszawa 2015, s. 25-26.

${ }_{11}$ Zob. D. Lebowa, K. Popik-Chorąży, Zadania i kompetencje organów ochrony środowiska po reformie ustrojowej państwa [w:] Dziesięć lat reformy ustrojowej administracji publicznej w Polsce, red. J. Parachomiuk, B. Ulijasz, E. Kruk, Warszawa 2009, s. 613.

12 Zob. P. Winczorek, Komentarz do Konstytucji Rzeczypospolitej Polskiej z dnia 2 kwietnia 1997 r., Warszawa 2000, s. 18. 
rekreacyjnych [...] lecz również ochronę [...] konkretnego krajobrazu, ukształtowania terenu czy sieci rzecznej, indywidualizującej Polskę i stanowiącej czynnik Jej tożsamości”'13.

Ochrona środowiska jest bez wątpienia ważnym zadaniem administracji publicznej. Znaczna część zadań ochronnych została powierzona samorządowi terytorialnemu.

Zapoczątkowany na skutek reform administracji z 1990 r. i 1998 r. postępujący proces decentralizacji zadań środowiskowych na rzecz samorządu terytorialnego doprowadził do poszerzenia katalogu ustawowych organów ochrony środowiska o organy samorządu wojewódzkiego. Na mocy ustawy z 29.07.2005 r. o zmianie niektórych ustaw w związku ze zmianami w podziale zadań i kompetencji administracji terenowej ${ }^{14}$ od 1.01 .2008 r. do organów ochrony środowiska należy sejmik i marszałek województwa (art. 19 pkt 6 ustawy). Powołując się na art. 376 p.o.ś. do organów tych po zmianach można było zaliczyć:

1) wójta, burmistrza, prezydenta miasta;

2) starostę;

3) sejmik województwa;

4) marszałka województwa;

5) wojewodę;

6) ministra właściwego do spraw środowiska ${ }^{15}$.

Natomiast od 15.11.2008 r. do organów ochrony środowiska należą: Generalny Dyrektor Ochrony Środowiska i regionalny dyrektor ochrony środowiska.

${ }^{13}$ Zob. P. Sarnecki, Uwagi do art. 5 [w:] Konstytucja Rzeczypospolitej Polskiej. Komentarz, red. L. Garlicki, Warszawa 2001.

14 Dz.U. poz. 1462 ze zm.

15 W. Radecki wyraża pogląd, „że są to najważniejsze (a nie wszystkie) organy ochrony środowiska" za Z. Bukowski, Zadania administracji terenowej w zakresie ochrony środowiska - próba oceny i propozycja zmian [w:] Rola samorządu terytorialnego w prawnym systemie ochrony środowiska, red. J Bucińska, D. Strus, R. Stec, Warszawa 2008, s. 54. 
Zadania ochronne samorząa terytorialnego w poszczególnych dziedzinach ochrony środowiska zostały stypizowane przez M. Górskiego, który wyodrębnił następujące typy zadań:

1) zadania o charakterze bezpośrednio wykonawczym (kreatywne, organizatorskie);

2) zadania o charakterze zobowiązująco-reglamentacyjne;

3) zadania o charakterze kontrolno-nadzorczym.

Zdaniem A. Barczak „zadania o charakterze organizatorskim polegają na podejmowaniu czynności oddziałujących na stan środowiska jako całość lub poszczególne jego części (elementy), których celem jest uzyskanie takiego rodzaju stosunków między elementami całości, aby części współprzyczyniały się do powodzenia całości”" ${ }^{16}$.

Do zadań organizatorskich na szczeblu centralnym zalicza się polityka państwa w zakresie ochrony środowiska, natomiast na szczeblu lokalnym wyrazem tego typu zadań są programy ochrony środowiska. Ustawa z 31.01.1980 r. o ochronie i kształtowaniu środowiska zobowiązywała do sporządzenia planu wojewodów. Dopiero po nowelizacji przepisów ustawy obowiązkiem tym zostały obciążone gminy ( $\mathrm{z}$ dniem 1.01.1998 r.), a następnie powiaty i województwa ( $\mathrm{z}$ dniem 1.01.1999 r.). Na skutek tych nowelizacji zdjęto obowiązek sporządzania planów z wojewodów. Lokalne programy ochrony środowiska są opracowywane przez organy wykonawcze samorządu gminnego, powiatowego i wojewódzkiego (tj. odpowiednio wójta, burmistrza i prezydenta miasta, zarząd powiatu i zarząd województwa). Zarząd jednostki wyższego szczebla opiniuje projekty lokalnych programów ochrony środowiska, w odniesieniu do programów wojewódzkich opiniuje je minister właściwy do spraw środowiska. Po zaopiniowaniu program zostaje uchwalony przez organy stanowiące samorządu gminnego, powiatowego i wojewódzkiego. Zgodnie $\mathrm{z}$ art. 18 ust. 2 p.o.ś. z wykonania programów organ wykonawczy województwa, powiatu i gminy sporządza co 2 lata raporty, które przedstawia odpowiednio sejmikowi województwa, radzie powiatu i radzie gminy.

16 Zob. A. Barczak, Zadania samorządu terytorialnego w zakresie ochrony środowiska, Warszawa 2006, s. 53. 
Odmiennym rodzajem programów środowiskowych są programy naprawcze, które tworzone są w celu doprowadzenia do przestrzegania naruszonych standardów jakości środowiska. Prawo uchwalania programów naprawczych uzyskały sejmiki województwa i rady powiatów. Innym rodzajem zadań o charakterze organizatorskim są wojewódzkie plany gospodarki odpadami. Ustawa z 14.12.2012 r. o odpadach ${ }^{17}$ zastąpiła ustawę z 27.04.2001 r. o odpadach. Po nowelizacji zostały zniesione gminne i powiatowe plany gospodarki odpadami. Wojewódzkie plany gospodarki odpadami, zgodnie z art. 35 ust. 7 ustawy o odpadach, muszą być zgodne z krajowym planem gospodarki odpadami. Ważną rolę wśród zadań organizatorskich odgrywają zadania w zakresie planowania przestrzennego. Tu istotną rolę kształtującą ład przestrzenny odgrywa gmina i województwo. Gmina - stanowiąc studium uwarunkowań i kierunków zagospodarowania przestrzennego gminy i miejscowy plan zagospodarowania przestrzennego, a województwo - uchwalając wojewódzki plan zagospodarowania przestrzennego.

Zadania o charakterze bezpośrednio wykonawczym polegają na eliminowaniu bądź ograniczaniu określonych zagrożeń powodowanych funkcjonowaniem społeczności lokalnych (np. zanieczyszczenie wód, powstawanie odpadów komunalnych, niszczenie powierzchni ziemi, terenów zielonych) ${ }^{18}$. Co do zasady są to zadania własne samorządu terytorialnego, finansowane ze źródeł indywidualnych. Wyjątkiem jest obowiązek rekultywacji gruntów, który jest zadaniem z zakresu administracji rządowej. Głównym wykonawcą tego rodzaju zadań jest gmina. Dzieje się tak na gruncie ustawy z 7.06.2001 r. o zbiorowym zaopatrzeniu w wodę i zbiorowym odprowadzaniu ścieków ${ }^{19}$. Również organizowanie ochrony przed bezdomnymi zwierzętami należy do zadań gminy (ustawa z 21.08.1997 r. o ochronie zwierząt $^{20}$ ). Gminę obciążają ponadto zadania w zakresie ochrony terenów zieleni i zadrzewień (art. 79 p.o.ś.). Spośród zadań o charakterze

\footnotetext{
${ }^{17}$ Dz.U. z 2018 r. poz. 992 ze zm. - dalej jako: ustawa o odpadach.

18 Zob. A. Barczak, E. Kowalewska, Zadania..., s. 90.

19 Dz.U. z 2018 r. poz. 1152 ze zm.

${ }^{20}$ Dz.U. z 2017 r. poz. 1840 ze zm.
} 
bezpośrednio wykonawczym rozbudowaną regulację mają zadania związane z utrzymaniem czystości i porządku w gminach, ujęte w ustawie z 13.09.1996 r. o utrzymaniu czystości i porządku w gminach $^{21}$. Do problematyki tej zastosowanie ma również ustawa o odpadach $^{22}$. Zgodnie z powołanymi regulacjami kompetencje w zakresie realizacji zadań związanych z utrzymaniem czystości i porządku zostały przypisane gminie oraz samorządowi województwa. Jedynymi zadaniami bezpośrednio wykonawczymi prowadzonymi w sposób jednorazowy są zadania w zakresie ochrony powierzchni ziemi. Cechuje je incydentalność, gdyż podejmowane są na skutek pojawienia się trudności wymagających naprawienia ${ }^{23}$. Regulacja w tym zakresie zawarta jest w ustawie z 3.02.1995 r. o ochronie gruntów rolnych i leśnych ${ }^{24}$. Zgodnie z ustawą podmiotem zobowiązanym do rekultywacji jest starosta.

W odróżnieniu od zadań kreatywnych (wykonawczych) realizacja zadań zobowiązująco-reglamentacyjnych odbywa się z wykorzystaniem instrumentu prawnego dającego możliwość kształtowania sytuacji prawnej podmiotów korzystających bądź oddziałujących na środowisko $^{25}$. Najbardziej typowym instrumentem prawnym jest decyzja administracyjna, choć przy realizacji zadań zobowiązująco-reglamentacyjnych wykorzystywana jest również forma uchwały. Organami odpowiedzialnymi za realizację zadań reglamentacyjno-zobowiązujących, zgodnie z art. 376 p.o.ś., są wójt, burmistrz, prezydent miasta, starosta, sejmik województwa i marszałek województwa. Określone rodzaje działań w tym zakresie podejmują również organy Inspekcji Ochrony Środowiska. Natomiast art. 378 p.o.ś. dokonuje szczegółowego podziału kompetencji pomiędzy starostą, regionalnym dyrektorem ochrony środowiska, marszałkiem województwa i wójtem (burmistrzem, prezydentem miasta). Zgodnie z tym przepisem głównym

${ }^{21}$ Dz.U. z 2018 r. poz. 1454 ze zm.

22 Zob. A. Barczak, Zadania..., s. 99.

23 A. Barczak, E. Kowalewska, Zadania..., s. 112.

${ }^{24}$ Dz.U. z 2017 r. poz. 1161.

25 Zob. D. Strus, Zadania realizowane przez jednostki samorządu terytorialnego w ochronie środowiska, „Administracja Publiczna Studia Krajowe i Międzynarodowe” 2012/1(19), s. 101. 
wykonawcą zadań jest starosta. Przed wejściem w życie 1.01.2008 r. i 18.11.2008 r. nowelizacji Prawa ochrony środowiska układ kompetencji był inaczej zorganizowany. Obowiązki te były podzielone między starostę, wojewodę i wójta (burmistrza, prezydenta miasta). Po wejściu w życie dwóch powyższych nowelizacji w zakres kompetencji wojewody weszli marszałek województwa oraz regionalny dyrektor ochrony środowiska. Tym samym wojewoda został pozbawiony swoich dotychczasowych zadań. Regionalny dyrektor ochrony środowiska jest właściwy w sprawach przedsięwzięć i zdarzeń na terenach zamkniętych. Zgodnie $\mathrm{z}$ art. 378 ust. 2a p.o.ś. marszałek województwa jest właściwy w sprawach:

1) przedsięwzięć i zdarzeń na terenach zakładów, gdzie jest eksploatowana instalacja, która jest kwalifikowana jako przedsięwzięcie mogące zawsze znacząco oddziaływać na środowisko w rozumieniu ustawy z 3.10.2008 r. o udostępnianiu informacji o środowisku i jego ochronie, udziale społeczeństwa w ochronie środowiska oraz o ocenach oddziaływania na środowisko ${ }^{26}$;

2) przedsięwzięcia mogącego zawsze znacząco oddziaływać na środowisko w rozumieniu ustawy z 3.10.2008 r. o udostępnianiu informacji o środowisku i jego ochronie, udziale społeczeństwa w ochronie środowiska oraz o ocenach oddziaływania na środowisko, realizowanego na terenach innych niż wymienione w pkt 1;

3) pozwolenia na wytwarzanie odpadów i pozwolenia zintegrowanego dla regionalnych instalacji do przetwarzania odpadów komunalnych i dla instalacji określonych w wojewódzkim planie gospodarki odpadami jako regionalne instalacje do przetwarzania odpadów komunalnych.

W większości zadania marszałka województwa $\mathrm{z}$ tej sfery to zadania z zakresu administracji rządowej. Pozostałe zadania zostały przypisane staroście, realizującemu je przede wszystkim w imieniu własnym i na własną odpowiedzialność. Wójt, burmistrz, prezydent miasta wykonują natomiast zadania związane ze zwykłym korzystaniem ze środowiska przez osoby fizyczne niebędące przedsiębiorcami.

${ }^{26}$ Dz.U. z 2017 r. poz. 1405 ze zm. 
Jak zauważa A. Bartczak, „analiza art. 378 pozwala stwierdzić, że głównym wykonawcą zadań zobowiązująco-reglamentacyjnych nie jest już starosta (jak było do 31 grudnia 2007 r.), ale przede wszystkim marszałek województwa. Rolę tego pierwszego organu bowiem zmarginalizowano ${ }^{27}$.

Regulacje prawne w zakresie reglamentacji korzystania ze złoża kopaliny uregulowane zostały w ustawie z 9.06.2011 r. - Prawo geologiczne i górnicze ${ }^{28}$. Uzupełniają je rozwiązania prawne zawarte w Prawie ochrony środowiska, ustawie z 27.03.2003 r. o planowaniu i zagospodarowaniu przestrzennym ${ }^{29}$ oraz ustawie z 3.02.1995 r. o ochronie gruntów rolnych i leśnych ${ }^{30}$. Ważniejsze zadania w zakresie reglamentacji korzystania ze złoża kopaliny zostały przyznane organom samorządowym w formie zadań z zakresu administracji rządowej. Zadania reglamentacyjne odnoszące się do ochrony obszarowej przy tworzeniu obszarów chronionych realizowane są przez samorząd województwa. Samorząd gminny posiada niewielkie kompetencje w tym zakresie. Zadania reglamentacyjne organów administracji samorządowej w zakresie ochrony indywidualnej realizowane są $\mathrm{w}$ formie uprawnień prawodawczych. Dopełnieniem są czynności materialno-techniczne. Kompetencje prawodawcze zostały przyznane radzie gminy. Wskazana jednostka właściwa jest do wprowadzenia odpowiednich form ochrony przyrody ( $\mathrm{tj}$. pomników przyrody, stanowisk dokumentacyjnych, użytków ekologicznych, zespołów przyrodniczo-krajobrazowych). W obrębie ochrony rybackiej spośród jednostek samorządu terytorialnego właściwy jest powiat oraz samorządowe województwo. W zakresie ochrony łowieckiej najważniejsze zadania reglamentacyjne zostały przyznane samorządowemu województwu i powiatowi. Marszałek województwa wydaje zezwolenie na odstępstwo od zakazu płoszenia zwierząt łownych. Starosta jest właściwy, w szczególnych przypadkach, do wyrażenia zgody na chwytanie i przetrzymywanie zwierzyny. Zadania

\footnotetext{
${ }^{27}$ Odmiennie D. Strus, Zadania..., s. 101.

28 Dz.U. z 2017 r. poz. 2126 ze zm.

${ }^{29}$ Dz.U. z 2018 r. poz. 1945.

${ }^{30}$ Dz.U. z 2017 r. poz. 1161.
} 
w zakresie humanitarnej ochrony zwierząt, jak również w zakresie ochrony terenów zieleni i zadrzewień obciążają głównie gminną administrację samorządową. Głównymi wykonawcami zadań w zakresie reglamentacji emisji jest starosta i marszałek województwa, gdyż tym organom przyznano wydawanie pozwoleń emisyjnych. Starosta i marszałek województwa są właściwi także w zakresie reglamentacji gospodarowania odpadami wydobywczymi oraz recyklingu pojazdów wycofanych z eksploatacji ${ }^{31}$.

Ostatnią grupę zadań środowiskowych realizowaną przez jednostki samorządu terytorialnego stanowią zadania kontrolno-nadzorcze. Istotą zadań kontrolno-nadzorczych jest badanie przestrzegania wymagań ochrony środowiska. Zadania te realizują przede wszystkim organy Inspekcji Ochrony Środowiska. Jednostkom samorządu terytorialnego zadania kontrolo-nadzorcze zostały przypisane mocą art. 379 p.o.ś. Z przepisu tego wynika, że kontrolę przestrzegania i stosowania przepisów o ochronie środowiska wykonuje marszałek województwa, starosta oraz wójt, burmistrz i prezydent miasta. Zgodnie $\mathrm{z}$ art. 288 ust. 1 p.o.ś. organem kontrolującym przestrzeganie przepisów w zakresie opłat za gospodarcze korzystanie ze środowiska jest marszałek województwa. W sytuacji nieuiszczenia przez zobowiązany podmiot opłaty bądź uiszczenia jej w wysokości budzącej zastrzeżenia marszałek województwa w drodze decyzji administracyjnej może ustalić jej wysokość w oparciu o własne ustalenia oraz wyniki kontroli przeprowadzone przez wojewódzkiego inspektora ochrony środowiska. Prawo ochrony środowiska w art. 194 uprawnia starostę do cofnięcia lub ograniczenia pozwolenia emisyjnego bez odszkodowania. Postępowanie w tym zakresie jest uruchamiane, jeśli instalacja jest nienależycie eksploatowana, przez co stwarza zagrożenie pogorszenia stanu środowiska w znacznych rozmiarach lub zagrożenie życia lub zdrowia ludzi. Realizacja kompetencji kontrolnych przez wójta, burmistrza, prezydenta miasta odnosi się do wydania decyzji nakazującej osobie fizycznej, której działalność negatywnie oddziałuje na środowisko, podjęcie działań mających na celu ograniczenie negatywnego oddziaływania na środowisko.

${ }^{31}$ Szerzej A. Barczak, E. Kowalewska, Zadania..., s. 148-171. 
Organy te mogą upoważnić do wykonywania funkcji kontrolnych pracowników podległych im urzędów marszałkowskich, powiatowych, miejskich lub gminnych bądź funkcjonariuszy straży gminnych. Kontrolującym Prawo ochrony środowiska w art. 379 przyznaje m.in. prawo wstępu wraz z rzeczoznawcami i niezbędnym sprzętem przez całą dobę na teren nieruchomości, obiektu lub ich części, na których jest prowadzona działalność gospodarcza, a w godzinach od 6 do 22 - na pozostały teren. Ponadto kontrolującym przysługuje prawo żądania pisemnych lub ustnych informacji oraz wzywania i przesłuchiwania osób w zakresie niezbędnym do ustalenia stanu faktycznego, jak również żądania okazania dokumentów i udostępnienia wszelkich danych mających związek z problematyką kontroli. Istotnym, z punktu widzenia realizacji zadań kontrolno-nadzorczych, jest przyznanie wskazanym organom prawa do występowania w charakterze oskarżyciela publicznego w sprawach o wykroczenia przeciwko ochronie środowiska. Organy kontrolne w przypadku stwierdzenia naruszenia przez kontrolowane podmioty przepisów o ochronie środowiska lub gdy występuje uzasadnione podejrzenie, że takie naruszenie mogło nastąpić, występują do wojewódzkiego inspektora ochrony środowiska o podjęcie odpowiednich działań będących w ich kompetencji, przekazując dokumentację sprawy. Organy kontrolne mogą korzystać ze środków prawnych przewidzianych nie tylko w Prawie ochrony środowiska. W przypadku podmiotów korzystających ze środowiska i będących przedsiębiorcami zastosowanie znajdzie ustawa z 6.03.2018 r. - Prawo przedsiębiorców ${ }^{32}$. Ustawa ta przewiduje w art. 60 ust. 3, iż w razie braku możliwości zawiadomienia wojewódzkiego inspektora ochrony środowiska o zagrożeniu środowiska wójt, burmistrz, prezydent miasta mogą podjąć decyzję wstrzymującą wykonywanie działalności gospodarczej na czas nie dłuższy niż 3 dni. Uprawnienia kontrolno-nadzorcze przewidziane zostały w przepisach ustawy o odpadach. Mocą art. 26 ustawy o odpadach zostały przypisane wójtowi, burmistrzowi, prezydentowi miasta uprawnienia w przedmiocie wydania decyzji nakazującej posiadaczowi odpadów usunięcie ich z miejsc nieprzeznaczonych do ich składowania lub magazynowania. Zgodnie z ustawą z 6.04.2004 r. o ochronie przyrody ${ }^{33}$

\footnotetext{
32 Dz.U. z 2018 r. poz. 646 ze zm.

${ }^{33}$ Dz.U. z 2018 r. poz. 1614 ze zm.
} 
nadzór nad przestrzeganiem obowiązków w zakresie ochrony przyrody został powierzony staroście oraz wójtowi, burmistrzowi, prezydentowi miasta. Natomiast z ustawy z 28.09.1991 r. o lasach ${ }^{34}$ wynika, że za nadzór dotyczący gospodarki leśnej w lasach niestanowiących własności Skarbu Państwa odpowiedzialny jest starosta. Jeśli chodzi o ochronę zwierząt łowieckich, to organy samorządowe nie zostały wyposażone w żadne środki korygujące ${ }^{35}$. Urząd gminy odbiera jedynie zawiadomienia o dostrzeżonych objawach chorób zwierząt żyjących wolno.

\section{Podsumowanie}

Przepisy z zakresu ochrony środowiska od wprowadzenia reform administracji w $1990 \mathrm{r}$. zostały znacząco przebudowane. Wiązało się to niewątpliwie z procesem decentralizacji administracji i przekazywaniem na szczebel lokalny zadań państwa.

Charakterystyczne dla zadań środowiskowych jest to, że nie wszystkie problemy z zakresu ochrony środowiska mogą być rozwiązywane na szczeblu lokalnym. O tym, jakie kategorie spraw można powierzyć samorządowi terytorialnemu, a jakie pozostawić administracji rządowej, przesądza najczęściej rodzaj problemu. Zdaniem R. Paczuskiego „W dziedzinie zachowawczej ochrony środowiska (konserwatorskiej ochrony przyrody) w innej skali muszą być rozpatrywane problemy zachowania dla potomności narodowego dziedzictwa naturalnego lub kulturowego w postaci np. parku narodowego albo pomnika historii niż np. ochrona zieleni o znaczeniu lokalnym np. parku wiejskiego albo tzw. indywidualnej ochrony przyrody w postaci pomnika przyrody, stanowiska dokumentacyjnego, użytku ekologicznego czy zespołu przyrodniczo-krajobrazowego" ${ }^{36}$.

34 Dz.U. z 2017 r. poz. 788 ze zm.

35 Zob. K. Gruszecki, Pozycja prawna samorzadu terytorialnego w nowym prawie łowieckim, ST 1996/7-8, s. 115.

${ }^{36}$ Zob. R. Paczuski, Rola samorządów terytorialnych w ochronie środowiska, „Zeszyty Naukowe Wyższej Szkoły Pedagogicznej w Bydgoszczy, Administracja Publiczna" 1997/1, s. 49. 


\section{Bibliografia:}

Barczak A., Zadania samorządu terytorialnego w zakresie ochrony środowiska, Warszawa 2006

Barczak A., Kowalewska E., Zadania samorzadu terytorialnego w zakresie ochrony środowiska. Aspekty materialne i finansowe, Warszawa 2015

Bukowski Z., Zadania administracji terenowej w zakresie ochrony środowiska próba oceny i propozycja zmian [w:] Rola samorzadu terytorialnego w prawnym systemie ochrony środowiska, red. J Bucińska, D. Strus, R. Stec, Warszawa 2008

Ciechanowicz-McLean J., Ochrona środowiska w działalności gospodarczej, Warszawa 2003

Ciechanowicz-McLean J., Prawo ochrony i zarządzania środowiskiem, Warszawa 2015

Gruszecki K., Pozycja prawna samorządu terytorialnego w nowym prawie łowieckim, ST 1996/7-8

Lebowa D., Popik-Chorąży K., Zadania i kompetencje organów ochrony środowiska po reformie ustrojowej państwa [w:] Dziesięć lat reformy ustrojowej administracji publicznej w Polsce, red. J. Parachomiuk, B. Ulijasz, E. Kruk, Warszawa 2009

Paczuski R., Ochrona środowiska. Zarys wykładu, Bydgoszcz 2008

Paczuski R., Rola samorządów terytorialnych w ochronie środowiska, „Zeszyty Naukowe Wyższej Szkoły Pedagogicznej w Bydgoszczy, Administracja Publiczna" 1997/1

Sarnecki P., Uwagi do art. 5 [w:] Konstytucja Rzeczypospolitej Polskiej. Komentarz, red. L. Garlicki, Warszawa 2001

Skoczylas A., Piątek W., Uwagi do art. 15 [w:] Konstytucja RP. Komentarz, red. M. Safjan, L. Bosek, Warszawa 2016

Strus D., Zadania realizowane przez jednostki samorzadu terytorialnego w ochronie środowiska, „Administracja Publiczna Studia Krajowe i Międzynarodowe" 2012/1(19)

Winczorek P., Komentarz do Konstytucji Rzeczypospolitej Polskiej z dnia 2 kwietnia 1997 r., Warszawa 2000

Zieliński E., Administracja rządowa i samorząowa w Polsce, Warszawa 2013 